\title{
PRACTICES IN INTERNATIONAL VALUE CHAINS: THE CASE OF THE KENYAN FRUIT AND VEGETABLE CHAIN BEYOND THE EXCLUSION DEBATE
}

\author{
PETER DANNENBERG* \& GILBERT M. NDURU** \\ *Humboldt-University at Berlin, Department of Geography, 10099 Berlin, Germany. \\ E-mail: peter.dannenberg@geo.hu-berlin.de \\ **Moi University, Department of Geography, Eldoret, 30100 Kenya. E-mail: gilnduru@gmail.com
}

Received: April 2011; accepted February 2012

\begin{abstract}
The emerging role of private standards as new forms of regulation and co-ordination in international trade and production is discussed in various fields including economic geography. A prominent example is the impact of the European standard GlobalGAP (former EurepGap) in Kenyan export horticulture. While today this standard is a quasi mandatory precondition for entering the EU market, several studies came to conclude that its high requirements led to market exclusion of most Kenyan farmers. This paper analyses how far farmers have in fact been excluded or have found alternative ways to enter the chain. Based on our own surveys, we identify and analyse different informal possibilities that are frequently used to produce for EU markets without a GlobalGAP certificate. Here we argue that informal production flows can take place even in highly standardised sophisticated consumer markets and should therefore be integrated into analyses on global value chains.
\end{abstract}

Key words: Value chain, standards, horticulture, agriculture, informality, GlobalGAP, Africa

\section{INTRODUCTION}

The fresh fruit and vegetable (later referred to as horticulture) supply chain between Kenya and the EU has been used as an example for the new developments in global trade and value chains in different studies (e.g. Barrett et al. 1999; Dolan \& Humphrey 2004). These studies showed that trade between Kenya and the EU has grown rapidly since the 1990s and that trading relationships have changed from a market-based relationship to a highly coordinated and integrated supply chain, which is dominated by large retail companies at the end of the chain. In this way the horticultural chain gave empirical evidence for the concept of 'global value chains' (Gereffi et al. 2005;
Gibbon et al. 2008; Nadvi 2008). In the late 2000 s, the chain received a lot of attention as the private, process orientated standard GlobalGAP (formerly known as EurepGAP; see e.g. Humphrey 2008; Ouma 2010), was widely introduced in the chain as a new private co-ordination and control system. Different studies indicated that the introduction of GlobalGAP as a quasi-mandatory standard led to serious problems for the majority of Kenyan small scale farmers who were not able to fulfil standard requirements and were therefore excluded from their main market (Brown 2005, Graffham et al. 2007). As a result, GlobalGAP was heavily discussed and criticised by scientists and development aid organisations (Humphrey 2008). The general discussion revolved 
around the question to what extent standards could change the way value chains are organised (Nadvi 2008).

New empirical findings (Mwangi 2008; Ouma 2010) suggest that noncertified farmers may find informal ways to produce for the chain nonetheless. Mwangi (2008) showed that neither Kenyan horticultural exports in general, nor the small scale farming-dominated contract farming system for vegetables faced a decrease of production since GlobalGAP became quasi-mandatory. Rather, both volumes increased. A recent study by Ouma (2010) indicates that some farmers might actually produce for EU retail companies without GlobalGAP certification via 'backstage arrangements'. Due to missing data, Ouma was not able to give quantitative evidence on the importance of these arrangements. However, an analysis of these arrangements can help to gain important empirical knowledge on what happened to the farmers, and gain general findings on the question in what way the organisation of a chain can be reshaped by private standards and which role informal arrangements might play (see research questions at the end of the Introduction section).

To fill this knowledge gap, this paper will first introduce the concept of global value chains and complement it with considerations on standards and informal economic activities. Based on this analytical framework, an empirical analysis on the issue in how far informal production flows (without formal GlobalGAPcertification) exist in the chain will take place. In doing so, this paper provides a differentiated view on the production and marketing systems of Kenyan farmers and the variable formal and informal supply systems of Kenyan exporters. This paper is the first to show the existence of large numbers of informal arrangements and therefore gives an explanation to why the export volumes of Kenyan horticulture is not declining even though only few farmers have been certified by GlobalGAP. Furthermore, it shows how different ways of informal arrangements could develop in the GlobalGAP system. Finally, the goal of this paper is to show that the debate on standards and exclusion in global value chains can generally be enriched by an examination of informal arrangements and production flows.
General discussion on horticultural value chains - In the rise of the global division of labour, value chains are marked by increasing spatial distances and complexity. In this process of globalisation, large transnational corporations have emerged which source their products in various ways from suppliers all over the world. To co-ordinate and control these supply chains, different governance strategies have developed, varying from loose market relations to highly integrated systems. In recent years, various theoretical frameworks have been developed to better understand these new forms of chains and their dynamic governance structures, for example, the concept of global production networks (see e.g. Coe et al. 2008) and the concept of global value chains (see e.g. Gereffi et al. 2005).

The concept of global value chains, especially, provides an analytical framework for a deeper understanding of different variations of co-ordination; governance and organisation in supply chains (see Nadvi 2008, Gereffi et al. 2005, Gibbon et al. 2008). In this framework, Gereffi et al. (2005) have developed a typology of global value chain governance with different degrees of co-ordination and power asymmetries (see Figure 1). The type of each chain depends on the complexity of transactions in the chain (degree of product and process specifications), the ability to codify transactions (e.g. through standards), and the capabilities (e.g. technological and management capabilities) of the involved suppliers. Market co-ordination is for example, characterised by low complexity of transactions and high capabilities of the suppliers, while hierarchical chains are marked by high complexity and low capabilities of the suppliers.

The typology of the concept has been critiqued as being highly stylised and representing only ideal forms (Nadvi 2008; Coe et al. 2008). While these critiques can be partly underlined by the results of this paper, the global value chains concept can describe and explain the relationships in international supply chains, namely, according to their identified key determinants complexity, codification and capabilities (Gereffi et al. 2005).

Studies on horticultural chains show that these chains are controlled by buyers at the end of the chain, that is, large retail companies. 


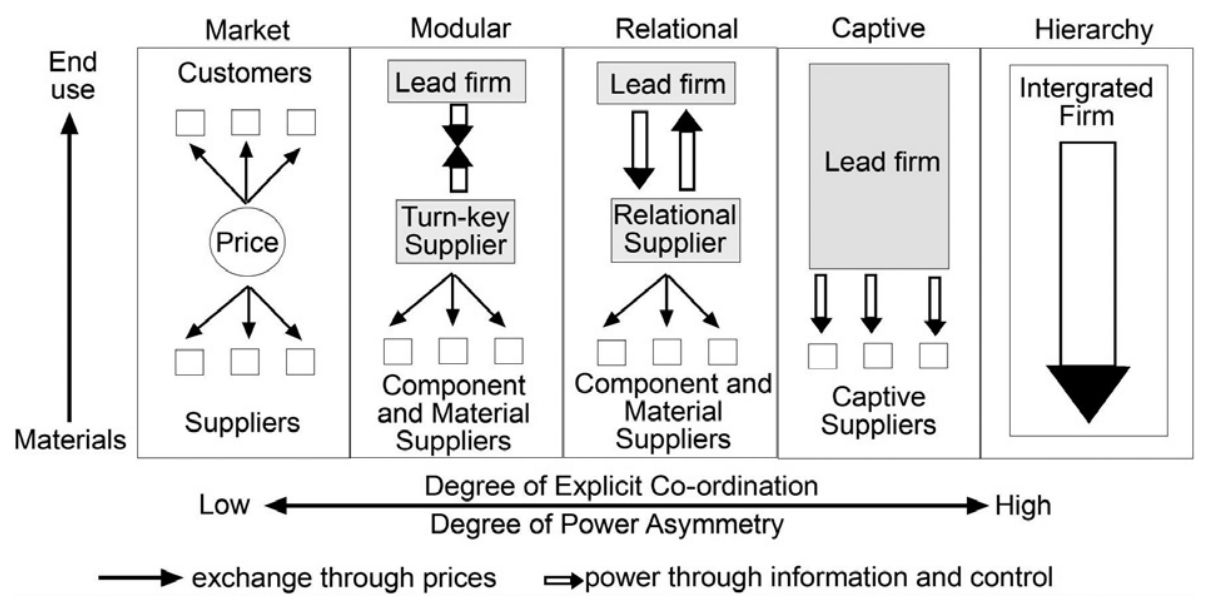

Source: Gereffi et al. (2005).

Figure 1. Global value chain governance types.

These lead firms make sure that their set requirements are adhered to in the regions of the producer, which are often located in Southern developing countries (Barrett et al. 1999, Dolan \& Humphrey 2000, 2004).

During the 1990s, the horticultural industries of some African export economies like Senegal, Zimbabwe and particularly Kenya strengthened their position in global trade as a result of neoliberal structural changes, a reduction of trade barriers, export support and changing consumer preferences (Dolan \& Humphrey 2000, 2004; Maertens \& Swinnen 2006). Up to this point, the Kenyan horticultural export chain had only been a loosely organised marked-based trade of primary products with a low degree of co-ordination (see Figure 1). Export traders bought produce from wholesale markets or at the farm gate and exported them to Europe, especially to the United Kingdom. In the 1990s, retail in Europe became more and more dominated by fewer, large retail companies (e.g. Marks \& Spencer, Carrefour). These retail companies developed new integrated and controlled supply systems and thereby the supply chains became more buyer-driven (Dolan \& Humphrey 2004).

Simultaneously, due to different food crises, consumers, politics and society demanded a stricter regulation of food safety and trace- ability (Jaffee 2005). As a result, supermarket chains started enforcing their own requirements and protocols along their supply chains (Ouma 2010). By the late 1990s, horticultural export trade organisation and co-ordination underwent a reorganisational change that led to the integration of all producers into a highly differentiated value chain with an explicit co-ordination framework controlled by the EU supermarkets ( Barrett et al. 1999; Gereffi et al. 2005). This development led to an increase in the number of retailers with direct links to large professional farms (Singh 2002; Minot \& Ngigi 2003). Here, we find more 'captive' relationships (Gereffi et al. 2005). Up until now, however, the majority of produce is still sold to the EU through Kenyan exporters and the sales volume of (mainly small scale) exporter contracted farming produce is also increasing (Mwangi 2008; FPEAK 2009).

According to the high degree of co-ordination and power asymmetry, the horticultural chain has attributes of a 'modular' value chain (Figure 1; Gereffi et al. 2005). Looking at the downstream end of the chain, relationships between retail companies and European importers move in the direction of modularity. Retail companies have reduced the number of importers and given their remaining suppliers greater responsibility regarding 
their own supply of goods within the chain (Gereffi et al. 2005). Importers are usually supplied with products by one or several exporters. Exporters may be solely export companies, co-operative movements and/or large producers who directly export their farm products. The more sophisticated demands of EU retail companies caused many Kenyan exporters to develop and implement their own 'quality management systems' (Ouma 2010, p. 203). In those systems, these exporters as well as the large scale producers often have a number of small scale producers from whom they source (additional) products. These farmers are usually managed and contracted by the exporter in an outgrower scheme (Dolan \& Humphrey 2004).

Standards in the value chain and the example of GlobalGAP in Kenya - A key component of the reorganisation of value chains, especially in food production, is private process-orientated standards. These standards developed as a reaction to the growing demand of consumers regarding transparency, safety, as well as socially fair and environmentally friendly production. Being a highly consumer sensitive sector, here, horticulture is a cutting-edge example of the proliferation of private standards. For the retail companies -as lead firms in the chain - private process orientated standards are a good way to additionally standardise product and process characteristics in the chain, reduce transaction costs and externalise risks and control functions (as several of these standards are controlled by a third party certification system; Nadvi 2008). Since the mid1990 s, private process orientated standards have rapidly spread around the globe (Jaffee 2005).

Today, probably the most important private standard in horticulture is GlobalGAP (Ouma 2010). The GlobalGAP standard includes sanitary, phytosanitary, social and environmental issues. GlobalGAP hence adopts a processbased, precautionary approach towards food safety and quality, requiring producers to systematically reduce and manage risks along the production process at farm level. A central requirement is the traceability of products, ensuring a re-connection between buyers and far-distant producers. GlobalGAP was launched by EU retailers in 1997. Since then it has evolved from an exclusively retailer-based coalition to a multi-stakeholder network, comprising retailers, producers, input suppliers, and certification bodies from the North and South alike. Nevertheless, the executive power remains in the hands of big retailers from the North. Since the mid-2000s, over 85 per cent of horticultural retailers' total sales volume were controlled under GlobalGAP (Graffham et al. 2007; GlobalGAP 2011). As a result, GlobalGAP has become a quasi-mandatory standard for most horticultural farmers producing for the EU market ( Brown 2005; Graffham et al. 2007). Due to this quasi-mandatory character and their extensive requirements, experts see standards like GlobalGAP as a market entry barrier for small scale farmers in developing countries. (Brown 2005; Graffham et al. 2007).

The example of Kenyan horticulture is a prominent examplar of this kind of development. Horticulture has continued to be one of the fastest growing sub-sectors in Kenya's export sector, growing at over 7 per cent per year. In 2007, Kenyan fresh fruit and vegetable exports reached a total revenue of US\$ 236 million (EPC 2011). Horticultural exports are now the leading export product (HCDA 2010). Most of these products end up on the EU market (Brown 2005).

However, with the proliferation of GlobalGAP, producers were forced to make knowledge- and capital-intensive investments in terms of upgrading farm equipment, ${ }^{1}$ and implementing new agricultural practices in order to comply with the standard. In addition, documentation, on-farm labelling and input calculation are required in order to ensure compliance, transparency and traceability. Finally, producers have to be audited by an internationally accredited third-party certifier, who usually flies in from the EU, a process which leads to additional costs. In total, these investments and running costs are usually higher than the total sales volume of a typical small scale farm. Even though, small scale farmers have the possibility to become certified as a group in order to share fixed costs, the individual input and efforts, even in a group, still remain considerable (FPEAK 2011; KHDP 2007). Since 2007, GlobalGAP has also established the more nationally orientated 
benchmark standard KenyaGAP ${ }^{2}$ but its proliferation was not that wide, yet. Hence, a large number of farmers fail to implement the standards, a fact which leads to their exclusion from the EU market (Brown 2005; Graffham et al. 2007; Humphrey 2008,). Graffham et al. (2007) calculated that in 2006 up to 60 per cent of the Kenyan farmers formerly producing for EU markets have been excluded from these markets in the context of GlobalGAP proliferation.

\section{Practical solutions and informal developments} - Graffham et al. (2007) point out, however, that this large percentage of excluded farmers has to be treated with care, and a more detailed investigation of this issue would be desirable. Indeed, it seems questionable that such a large percentage of farmers had really been excluded from the chain. As mentioned above, ever since the prevalence of GlobalGAP in Kenya, the sales volumes of Kenyan horticultural export have continued to grow rather than to show a decline (Mwangi 2008).

However, analyses on the reactions of farmers who did not succeed in applying for certification have not been numerous so far. Graffham et al. (2007) suggest that the excluded farmers have shifted to local markets or less stringent export markets. Mithöfer et al. (2008) also assume such a shift, but they find too that existing research does not provide sufficient insight into the actions that are in fact taken by farmers who are affected. As Ouma (2010) indicates, some farmers might still produce for EU retail companies via 'backstage arrangements'. According to him, these arrangements can appear as compromises between exporters and importers because of generally high levels of quality production among farmers even without certification, and clandestine sourcing practices.

Empirically, it is interesting to find out how and to which extent the exporting small scale horticultural farms, which are a highly important income source for the population in rural areas (Graffham et al. 2007; FPEAK 2011), are really excluded from their main markets or could find alternative ways of dealing with the situation.

According to the general discussion among academics, the analysis of such backstage arrangements may improve the linkage between the debate on global value chains with the current discussion on informality (see e.g. Castells \& Portes 1989; Chen 2004). The discussion on informality cannot be used to characterise structural units or processes only but also economic exchanges and flows. However, the contribution of informal production flows into formalised production networks has received relatively little scientific recognition. In the past, formality and informality were seen as polarised elements of the socio-economic structure with only limited interactions in a dualistic system (Kulke 2009). Recent studies in urban production-consumption systems, however, indicate that informal production flows from small and micro businesses may substantially contribute to highly formalised value chains (Chen 2004). Here linkages can be achieved, for example, through hegemonic actors who connect the informal and formal ties and negotiate between the exchange modes. Studies on the question to what extent informal production flows can contribute to highly standardised sophisticated consumer markets are missing so far.

For small scale producers in Kenya, it seems possible, however, that even though a much stronger integration of the production process and high standardisation have taken place in recent years, also informal ways of producing for the chain could develop. These production methods give formally non-certified farmers the possibility to also supply the chain. The identification and analysis of such types of informal flows into the highly standardised and integrated GlobalGAP system can therefore give further evidence and explanation of the possible importance of informal flows even in highly standardised international value chains. Our paper aims to fill this knowledge gap by giving more empirical clarity concerning the extent to which large numbers of small scale producers in Kenya are really excluded from the EU market by GlobalGAP or are producing for it all the same. In this context, we focus on the way the actors in the chain deal with the standard and the fulfilment of its requirements. Here, we distinguish between the GlobalGAP certification as the most important formal precondition to sell to most EU supermarkets, and potential informal ways of Kenyan producers 
and traders of dealing with it or by-passing it. Our aim is not only to identify different possible informal arrangements (as Ouma started with in 2010), but also to show, first exemplary, indications regarding their quantitative importance, and identify influential factors and characteristics of their (different) nature. Against this background this paper raises the following questions:

- How is the horticultural value chain from Kenyan producers to export markets organised and governed today?

- Which role does GlobalGAP play in this organisation and in particular for the sales opportunities and arrangements of Kenyan farmers?

- How far is it possible to enter the value chain informally without a GlobalGAP certification?

- What is the nature of these informal arrangements?

\section{DATA AND METHODOLOGY}

To answer these questions, an empirical study was conducted (October 2008-August 2009) including both a quantitative survey of farmers in the production region Mt. Kenya, and qualitative interviews with experts and actors along the value chain.

Selection of the study region - One of the most important horticultural producing areas is the Mt. Kenya region (Waitathu 2008). It is endowed with a generally favourable climate for horticultural production. However, the climate is characterised by different zones, which are replicated by marked zoning of product varieties in respect to the altitudinal location of respective growing areas (see Figure 2). Land holdings in the area - typical for Kenya - are generally less than 15 ha (McCulloch \& Ota 2002) and managed as family ventures. Since the 1990s horticultural export production has become the most important form of livelihood in the region. Export products are, above all, French beans, snow peas, avocados and mangoes (Waitathu 2008). In 2005, about 4000 horticultural farmers in the area were producing for export (Mithöfer et al. 2008).
Data collection and analysis - A mixed methods approach involving the use of standardised questionnaires and oral interviews with farmers, respective members of the value chain and other stakeholders was applied to gain insight into ongoing developments concerning the challenges of GlobalGAP in the chain and the region.

An initial survey based on interviews followed by a pre-test of the questionnaire (2008) was conducted. First hand information on farm characteristics, chain organisation and on linkages (material and immaterial, formal and informal) between farmers and different stakeholders was gathered. ${ }^{3}$ Later on research assistants familiar with the region collected the field data.

Due to unreliable records on village addresses and total numbers of horticultural farms in the area of study and in Kenya in general (Mithöfer et al. 2008; Ouma 2010), a sample of farmers from 41 villages was purposefully selected, the inclusion criterion being that they grow for EU export markets using GlobalGAP. The farmers were asked the following questions: (1) Do you use a standard?; (2) Which standard do you use?; and (3) Do you produce for the European market? Farmers were only selected if they answered questions 1 and 3 with 'yes' and question two with 'GlobalGAP' or 'KenyaGAP'. Yet, question 2 did not indicate whether farmers also had a formal certificate. Based on the experiences during our pre-test, we therefore included a further question at a later point in the questionnaire: Do you have a standard certificate? Here farmers could tick 'GlobalGAP Option 1 (individual)', 'GlobalGAP Option 2 (group certificate)' or the same for KenyaGAP. The last option was 'I do not have any certificate'. Those farmers, who explicitly marked the latter, were later regarded as producing for the market via informal arrangements.

Contacts to the sample farmers were made directly with the help of local leaders in each village. The locations were selected by taking into account the different elevation levels of the area in order to capture the various growing and marketing practices, which differ with the elevation.

Snowball sampling (Biernacki \& Waldorf 1981) was further employed to identify 


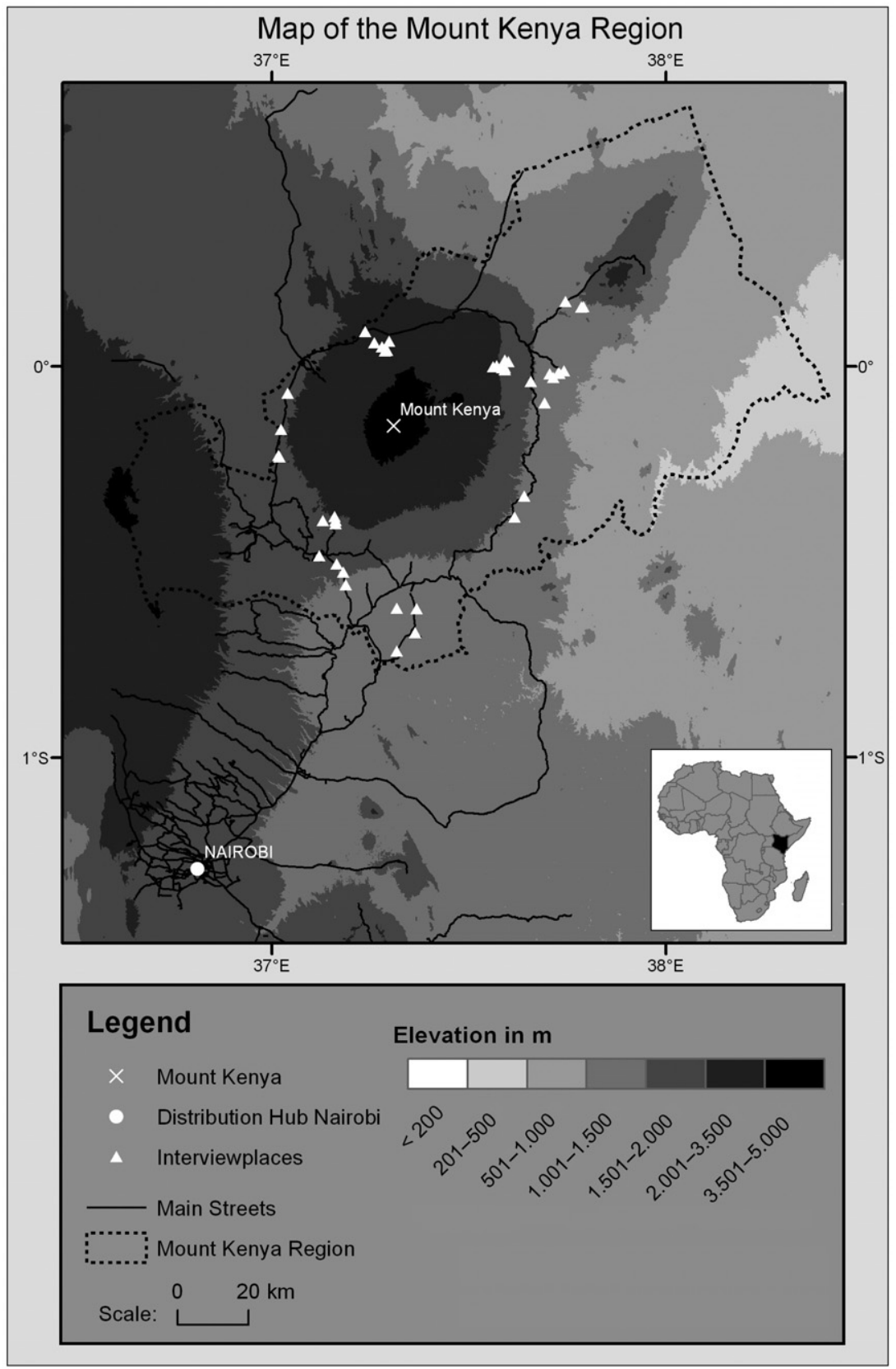

Source: Own design; cartography by Manuela Kunze; ILRI (2007), Aster (2009).

Figure 2. Location of the study area in Kenya. 

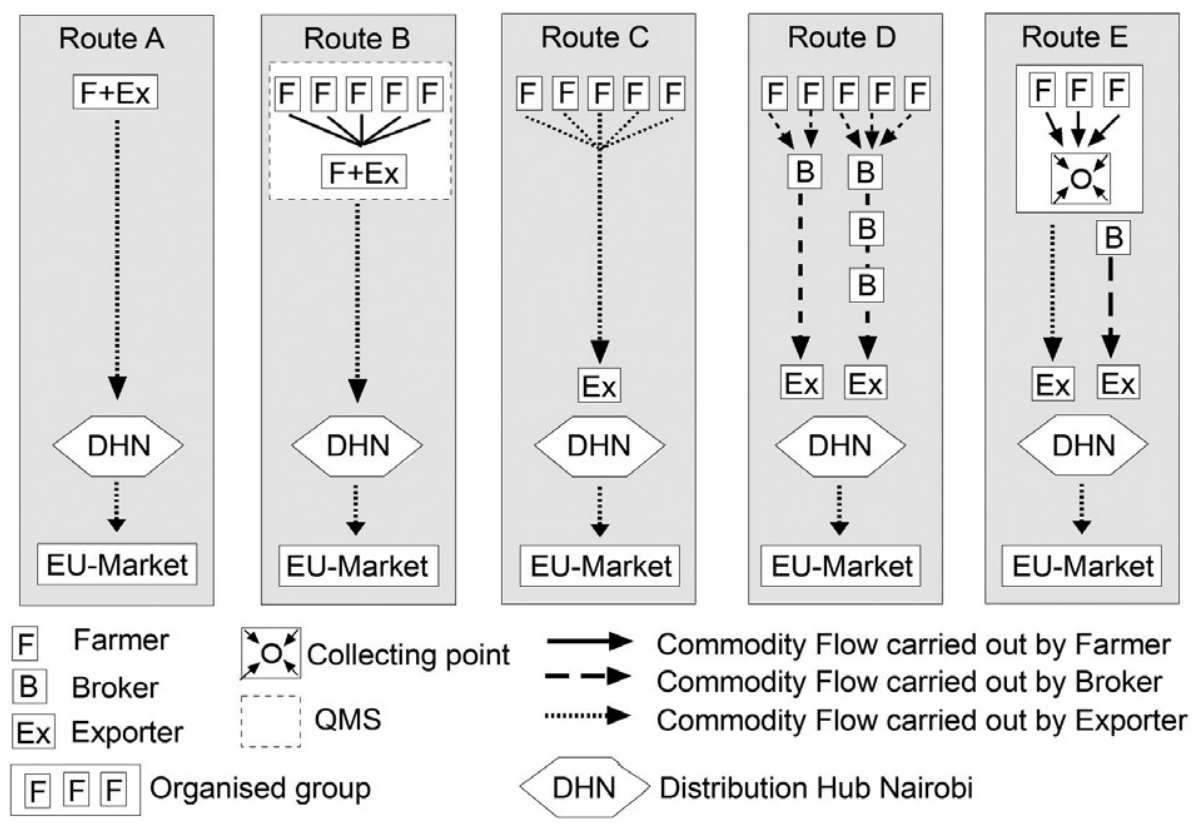

Source: Own figure based on own survey.

Figure 3. Routes of horticultural exports from the farm gate.

respective producers that grew crops under GlobalGAP in all 41 villages. Following information from GlobalGAP users, respective buyers of products, transporters and exporters were identified and contacted for further interviews along the chain. The interviews were semi-structured. The interviews with farmers left room for narrative descriptions on the usage of the standard, marketing practices and the trading relations with their buyers. The interviewed traders included brokers as well as several exporters and leading members of the Fresh Produce Exporters Association of Kenya (FPEAK). Furthermore, different supply chain managers of European retailers and importers as well as other stakeholders (members of NGOs and public organisations related with horticultural export) were interviewed to validate the generated data.

In total, 156 producers (including one large scale exporting company (>1000 ha), eight larger farms with 15-50 ha and 147 small scale farms ${ }^{4}$ with less than 15 ha were surveyed ${ }^{5}$ and 55 interviews took place.
After the completion of the survey, the standardised data were processed with SPSS (IBM: Armonk, NT) and a statistical summary was produced. The results were grouped into the different buyer linkages and according to the different formal and informal ways in which farmers deal with the standard. While the quantitative analysis was only able to identify direct buyer linkages, the qualitative interviews with farmers, belonging to these groups, and along the value chain, indicated further indirect and vague linkages (see Figure 3).

The influence of the different distribution challenges the farmers were confronted with and the question how to use the standard were first measured by cross-table calculation. In order to identify clear causalities, quantitative results were interpreted by using the interviews as well as referring to related literature.

\section{RESULTS}

Categorisation of horticultural exports - Ever since the 1990s, chain integration and the 
Table 1. Farmers using different Routes from the farm gate.

Route A Route B Route C Route D Route E left Route E right

\begin{tabular}{lllllll}
\hline Number of farms & 1 & 56 & 24 & 46 & 32 & 17 \\
Percentage of total sample (156) & 1 & 36 & 15 & 29 & 21 & 11 \\
\hline
\end{tabular}

Source: Own survey; the table can only give the approximate amount of farmers using the distribution channels. ${ }^{7}$ As several farmers use more than one distribution channel, the cumulated percentage exceeds $100 \%$.)

requirements put forward by large retailers have been increasing. While the dominant oligopoly position of large EU retail chains can be indicated by their share of total sales volumes in France, for instance, the five largest companies hold over 90 per cent of total sales volumes (2004); in Germany, over 80 per cent in 2007 (Jaffee 2005; TradeDimensions 2010) - our qualitative results were clearly able to underline and describe this dominance (see also Dolan \& Humphrey 2004). As stated in our interviews with different EU retailers and all of the eight interviewed importers, buying conditions concerning prices, contract durations, product quality and volumes are mainly set by the buyer as 'the driving force who sets the rules' (Austrian importer). In most cases, retailers take the right to change their demand volumes on short notice and the importer is forced to react flexibly. For importers this means that they need to stay in contact with suppliers that can fulfil these highly volatile demands in terms of quantity, and still meet the sophisticated GlobalGAP quality demand. Keeping in mind that production is dependent on the growth phases of the crops, flexible production on high process and quality standards is a huge challenge for the importers: 'I need to sell in flexible volumes that meet certain standards including GlobalGAP, but the products are perishable and the farmers need to plan' (German importer). While some importers actively try to find joint solutions, the general problem of this flexible demand is passed down to the suppliers, in this case the Kenyan exporters. Until this point, the structure and the relationships within the chain can be considered as a high power asymmetry with few retail companies as lead firms and a high degree of explicit codification. However, a high grade of responsibility for the supply chain is still handed down to the importers and even further down to the exporters. In this way, the chain shows important attributes of a 'modular value chain' in Gereffi et al's (2005) terms. While earlier works of Dolan and Humphrey (2004) outlined the important functions of importers, namely to monitor and audit producers, these functions have mainly been outsourced to GlobalGAP. Today, the role of importers is generally limited to that of a wholesaler.

Instead, it is now the Kenyan exporters that take on high responsibilities and control functions and organise the supplying producers according to the customer's specifications (which Gereffi et al. 2005, p. 84 call 'turn-key services') Regarding the Kenyan part of the chain, Kenyan exporters have different types of supply routes, which each have different degrees of co-ordination and integration (see Figure 3 and Table 1). While some exporters source from their own large farms (route A) and therefore have more 'hierarchical' control on their production segments, most exporters (additionally) buy from individual small scale farmers, organised farmer groups or from so called 'brokers' (small regionally based middlemen and transporters). This means that there are several direct and indirect connections between the producer and the exporter which make it complicated to clearly define the chain as a certain type of value chain.

The most direct way for small and medium producers is to sell their produce to an exporter. This exporter either has his own farm in the region ${ }^{6}$ which works together with local small scale farmers (route B) or he is located in Nairobi but has his own logistics system to collect products from the farm gate or a collecting point in the region (route $\mathrm{C}$ ). Exporters are usually larger professional companies which organise transportation with refrigerated or 
non-refrigerated motor trucks. They are in direct contact with the importers and large retail chains in Europe and other countries. Most of them are registered with the FPEAK and in this case they are connected to GlobalGAP (FPEAK 2011).

In route $\mathrm{B}$, the exporter usually integrates the farmers into a quality management system (QMS). The majority of these exporters have established QMS for their supplying farmers for several years already. In these systems they supervise and advise them face-to-face through technical assistants on the farm (for example, management and production methods; Minot \& Ngigi 2003). The farmers are technically guided and financially supported. In general, this also includes most costs and efforts related to GlobalGAP (KHDP 2007). The 'exporter is certified and has full control of the farmers who produce for him and use the QMS' (Kenyan Exporter). Today, QMS are common in Kenya and the Mt. Kenya region and consequently route $\mathrm{B}$ was the most frequently used distribution channel. The development of QMS (as well as virtually every interview held in the Mt. Kenya region) reveals: Even though the production processes of the chain have been codified and formally standardised through GlobalGAP, the standard obligations and the customer's specifications are (apart from the cost issue), too complex for large numbers of Kenyan farmers to fulfil on their own, so they need technical guidance and training on the job. Or to say it in the words of Gereffi et al. (2005), the complexity of transactions is too intricate for the farmers and their limited capabilities to simply use given codes. To fulfil the standards, they therefore need relational support.

While export companies/farms are well organised and equipped with all requisite processing and transportation infrastructure, the main alternative, the brokers (route $\mathrm{D}$ and $\mathrm{E}$ on the right) often have to hire cargo vehicles from transport companies. Furthermore, according to interviews with eight farmers, three exporters and three external experts, brokers are often considered unreliable, especially with respect to payments and adherence to agreements. This was explained by an expert of the Promotion of Private Sector Development in Agriculture Programme (PSDA): 'Brokers betray the farmers ... not honouring the contract or lying is unfortunately no exception ... For example they cheat with weights at the market. They have for example weights of $140 \mathrm{~kg}$ which they claim that they have only $100 \mathrm{~kg}$, so the farmers sell to the wrong weight'.

Finally, due to their non-existent or limited training and experience on horticultural production processes and to their missing contacts to importers and GlobalGAP members, the brokers usually lack sufficient information and knowledge about the standard and therefore capability to support the farmers. However, brokers deal with producers in peripheral regions, who are not accessed by exporters for a variety of reasons. Here, producers suffer from poor infrastructure and roads, which make their marketing efforts difficult. To them, brokers are often the only channel that connects them to exporters and external markets. The brokers in turn sell their products directly to an exporter(s) (Figure 3, route D left). In some instances, they sell to other brokers (Figure 3, route $\mathrm{D}$ right).

Some farmers have formed organised groups (e.g. organised on a village level) which are connected by a working agreement that stipulates their responsibilities and benefits. Such groups operate on a co-operative concept guided by a set of by-laws and their roles are to make contacts, organise collection and storage of produce as well as facilitate training with requisite standards and certification (which usually involves group certification). Such organised farmers (which are not necessarily group certified) first bring their products to a central group collection point, from where they sell jointly to an exporter (Figure 3, route E left) and/or broker (Figure 3, route E right).

Informal backstage arrangements - As mentioned, the required proof of one's fulfilment of GlobalGAP requirements is a formal certificate issued by either GlobalGAP or KenyaGAP, either individually or as a group. However, only 25 per cent of the producers surveyed (who stated that they 'used' GlobalGAP and produce for EU market; see Table 2) had a formal certificate of their own. Like other studies (Graffham et al. 2007; Mithöfer et al. 2008), our study underlined two main reasons for this low number of certification: the high costs and the complexity of the standards. Eighty one per 
Table 2. Certification of farmers in the Mt. Kenya Region (sample 156 farms).

\begin{tabular}{|c|c|c|c|c|c|c|}
\hline & $\begin{array}{l}\text { Without } \\
\text { formal } \\
\text { certification }\end{array}$ & $\begin{array}{l}\text { GlobalGAP } \\
\text { individual } \\
\text { (Option } 1)\end{array}$ & $\begin{array}{l}\text { GlobalGAP } \\
\text { group } \\
\text { (Option 2) }\end{array}$ & $\begin{array}{l}\text { KenyaGAP } \\
\text { individual } \\
\text { (Option 3) }\end{array}$ & $\begin{array}{l}\text { KenyaGAP } \\
\text { group } \\
\text { (Option } 4)\end{array}$ & Total \\
\hline $\begin{array}{l}\text { Number of farmers and } \\
\text { type of certification }\end{array}$ & 117 & 6 & 24 & 3 & 6 & 156 \\
\hline $\begin{array}{l}\text { Percentage of total } \\
\text { sample (156) and type } \\
\text { of certification }\end{array}$ & 75 & 4 & 15 & 2 & 4 & 100 \\
\hline
\end{tabular}

Source: Own survey.

Table 3. Share of not formally certified Farmers using different Routes for export.

\begin{tabular}{|c|c|c|c|c|c|c|c|}
\hline & $\begin{array}{l}\text { Route } \\
\text { A }\end{array}$ & $\begin{array}{l}\text { Route } \\
\text { B }\end{array}$ & $\begin{array}{l}\text { Route } \\
\text { C }\end{array}$ & $\begin{array}{l}\text { Route } \\
\text { D }\end{array}$ & $\begin{array}{l}\text { Route } \\
\text { E left }\end{array}$ & $\begin{array}{l}\text { Route } \\
\text { E right }\end{array}$ & Total $^{\mathrm{a}}$ \\
\hline Number of farms & 1 & 56 & 24 & 46 & 32 & 17 & 176 \\
\hline Percentage of total sample (156) & 1 & 36 & 15 & 29 & 21 & 11 & 113 \\
\hline $\begin{array}{l}\text { Number of farms without formal } \\
\text { certification }\end{array}$ & 0 & 47 & 22 & 39 & 7 & 6 & 121 \\
\hline $\begin{array}{l}\text { Percentage of farms of the respective } \\
\text { route without formal certification }\end{array}$ & 0 & 84 & 92 & 85 & 22 & 35 & $69^{\mathrm{b}}$ \\
\hline
\end{tabular}

Source: Own survey.

Notes: ${ }^{a}$ As several farmers use more than one distribution channel, the cumulated percentage exceeds 100 per cent (156 farms).

b Especially for those farmers holding a certificate, it is much easier to use several distribution routes and therefore they are counted in each route, while those without formal certification are usually dependent on one buyer and therefore only appear in one route. As a result the percentage of farms without formal certification in this table is lower than in total $(75 \%)$.

cent of the total sample considered the standards as very expensive or too expensive to fulfil and 32 per cent considered them as very time intensive or too time intensive to fulfil.

As a result, a large number of uncertified farmers are contributing to the chain. This provides evidence that there are different ways (and probably qualities) of supplying the chain with uncertified products. In addition, this questions the previously claimed dimension of exclusion in studies like the one by Graffham et al. (2007). Instead of being excluded, our results indicate that a large number of farms are still producing for the EU market through these arrangements. Second, it also questions the targeted transparency and tightness of the GlobalGAP system.

Concerning the distribution channels, most of the formally non-certified farmers $(62 \% ; 76$ farms in total; route B, C and E left; see Table 3) are producing for exporters. Thirty seven per cent ( 45 farms in total; route D and E right; see Table 3 ) of the formally non-certified farmers are (partly additionally) producing for brokers. The participation of non-certified farmers in the chain can be explained in a variety of ways, depending also on the different routes and integration of the farmers into the chain.

Generally, it is a fundamental challenge for certifiers to control all steps of the production process. As a German certifier said: 'We can control the processes on those farms which have a certificate, but we do not know if every product comes from the farm. Indeed we suspect that in the less developed states there are a lot of certified farmers, or even the majority buying additional products from other farmers or brokers and sell them under their label'. 
According to our interviews, the most integrated and reliable route is of course route A. Indeed it is where the chain becomes vague so that traceability becomes questionable. Our interviews further indicated the limited reliability of brokers (route $\mathrm{D}$; $\mathrm{E}$ and $\mathrm{F}$ right) who often use questionable methods which includes mixing the produce of certified and uncertified produce. One exporter remarked, for instance: 'Yes it is true; we cannot assure that the brokers bring other products than we wish to'.

However, the majority of non-certified farmers sell their produce directly to exporters. This can be explained in two ways. First, it is common practice that during peak demand times, exporters also buy uncertified products. According to independent experts (interviews with a certifier and several scientists from Kenya and EU 2009), some importers and retailers in Europe ${ }^{8}$ are aware of it.

The most common way of participation is, however, the long-term integration of noncertified farmers into exporter schemes (route B; see table 3). In this way, farmers who are not certified sell their produce under a GlobalGAP certificate issued for their contractor (the certified large exporting farm which controls the other farms in the QMS). This was described by an exporter as follows: 'Strict records of chemicals used and modern storage facilities are not possible for small scale farmers. The costs are much too high, higher than their sales volumes ... They cannot all be certified under GlobalGAP stipulations. Every exporter is certified, but most farmers not. So we do not require certification ... we just want the farmers to be "compliant" and we test them ourselves' (Kenyan exporter). This practice was observed at farm level and confirmed by different experts (e.g. donors and members of the Kenyan horticultural development agency (HCDA)). However, these backstage arrangements do not necessarily mean that these farmers do not meet the requirements of the standards. In practice, most of the non-certified producers who bring their products into the chain under route $\mathrm{B}$ and $\mathrm{E}$ (left) are strictly controlled by their direct buyers who make efforts to train them. Some even have agreements with their buyers in which they set milestones for a future certification. However, the current situation of these farmers means that a formal certification and an independent third party inspection are not given. 'We suspect that is a widespread practice in developing countries, but it is not a formal and legitimate compliance according to GlobalGAP' (European certifier).

\section{DISCUSSION}

While product and process specifications are codified according to GlobalGAP, the system still has elements of a relational value chain (Gereffi et al. 2005). Even though they are codified, the control of GlobalGAP process requirements in particular are very difficult to guarantee in the different supply routes and relations. This is one reason why informal arrangements could evolve and why a full implementation of GlobalGAP certification has been limited so far (see below).

The high obstacles for becoming certified make it (nearly) impossible for small and medium sized farms to continue producing for their main market the EU under GlobalGAP. As several studies (e.g. Graffham and Cooper 2008), have already observed, our results underline that the costs and efforts both for the implementation and long term maintenance of a formal GlobalGAP certification are usually too high for small scale farmers with their low financial and technical capabilities.

For those who are integrated into a QMS, knowledge and financial support are given by the exporter (route B), while those farmers who are integrated into a group support each other and can use group certification or have other advantages of economies of scale (e.g. by cost sharing for larger equipment, joint purchase). However, as stated by different farmers, even with the necessary financial resources and technical equipment, the requirements of the standard are still highly complex and often inscrutable for an average Kenyan farmer. ${ }^{9}$ Here, exporters and groups can alleviate complex technical problems through knowledge transfer.

Based on the different identified routes, support systems and the capabilities of the buyers, two different types of informal arrangements (with mixed types in between) can be categorised: 
1. Informal arrangements in integrated and internally controlled systems: These informal arrangements appear in route $\mathrm{B}$, partly in route $\mathrm{E}$ left. Typical identified characteristics are:

- Strictly internal control through quality management systems (QMS)

- Long term relationships

- Necessary financial support and knowhow is provided by technical assistants with high capability face-to-face (relational)

- Agreement between the exporter and the farmer, sometimes also 'compromises between exporters and importers' as identified by Ouma (2010; p. 216) where exporters act as hegemonic actors

- GlobalGAP requirements are fulfilled (aim is to reduce the costs of a formal certification, especially the high costs of hiring a certifier to audit the process).

2. In contrast, especially route $\mathrm{D}$ is marked by uncontrolled informal arrangements which can be characterised as:

- Market based relations, short term with a low level of trust between the actors

- Low capability of the buyer to provide the farmers with know-how or financial support.

- Uncontrolled and unorganised arrangements (no QMS or support system)

- Therefore high risk that farmers do not fulfil most GlobalGAP requirements (except if there is other support or access to knowledge, for example, by NGOs or associations)

- Based on 'clandestine sourcing practices' (Ouma 2010; p. 216) - often no agreement with the exporter, except during peak demand times

- Mixing non-certified products with certified products usually without the knowledge of the certified producers (own interviews).

Regarding the other routes, different degrees of co-ordination, support and control occurred. In route $\mathrm{C}$, informal arrangements were applied by farmers buying additional products from uncertified neighbours. Regarding route $\mathrm{E}$ right, the degree of control depended on the level of co-ordination in the group, while in E left sometimes also co-ordination, control and support of the exporter took place.

While the uncontrolled informal arrangements involve the described risks, exporters, brokers, and even some large producers sometimes do still need these uncontrolled routes and channels to flexibly produce the highly volatile volumes required by the $\mathrm{EU}$. This means that both producers and traders in Kenya have a strong interest in keeping the small scale farmers integrated, even without certification. Here they see the only way to fulfil the demand based on the conflicting EU retail company requirements of flexibility and highly challenging product and process obligations. ${ }^{10}$

So far, the two discussed solutions to overcome the lack of certified products (Group certification and the benchmark KenyaGAP) have only partly been able to overcome this bottle neck. Especially group certification has been regarded as a possible solution to get farmers formally certified without high efforts and costs for the farmers (Graffham \& Cooper 2008). As shown in Table 3, the number of informal arrangements is far lower for group certification (route $\mathrm{E}$ left and right). However in our sample, 22 per cent of route $\mathrm{E}$ left and 35 per cent of route $\mathrm{E}$ right still had no formal group certificate. According to our interviews, several problems occur here. First, a group certification is quite expensive (about $\$ 700$ depending on the size of the group; see also Graffham \& Cooper 2008) and therefore much more costly than informal arrangements. Also, a group has to be established as a legal entity, which is challenging due to mistrust among would-be members. Here, group members often tend to consume the benefits of the group without contributing to the efforts (free rider problem) or opt out of joint marketing contracts. Moreover, in cases where no professional help was given by exporters or donors, fulfilling the requirements to get certified still remained difficult, even for a group (see also Asfaw et al. 2008). Regarding KenyaGAP, our observation was that most farmers in the areas around Mt. Kenya had not heard of it, or knew producers that had experiences with it. ${ }^{11}$ In addition, Ouma (2010) points out several weaknesses of the standard (including high costs, 
and limited buyer acceptance) which limit its proliferation. As Table 2 shows, only nine farmers $(6 \%)$ used this standard.

\section{CONGLUSION}

We agree with the state of the art that it is hard for Kenyan farmers to get a GlobalGAP certification. However (and this is new!), this does not mean that there is only a dichotomy of being certified or being excluded. Based on the co-ordination and structure of the value chain and the institutional level in which it is embedded in Kenya, Kenyan producers and traders have developed different ways of informal integration for not formally certified producers to enter the supply chain of EU retail companies. In addition our results indicate in the first place that this is actually done by large numbers of farmers. This does not necessarily mean that the quality and process requirements are not fulfilled, as different measures are taken and controlled (e.g. by exporters at the farm level). Generally, our results are the first to show that the integration and standardisation even of highly sophisticated consumer markets do not necessary lead to a large exclusion of small scale businesses of developing countries. Second, the introduction of standards like GlobalGAP has so far not necessarily stopped the development or persistence of informal non-certified production flows into the chain. Informal production flows can play a serious role in global value chains and this role should be taken into account at least for analysing the impact of standards in the chain.

\section{Acknowledgements}

We would like to thank Amelie Bernzen (Cologne), Barbara Feulner (Erlangen) and Stefan Ouma (Frankfurt) as well as our anonymous reviewers for their valuable comments.

\section{Notes}

1. Including pesticides, storage and grading rooms, toilet and shower facilities to ensure farm hygiene.

2. In 2007, GlobalGAP also launched the official benchmark standard 'KenyaGAP'. KenyaGAP includes the same obligations and control points but aims to interpret the technical criteria and obstacles of GlobalGAP in a way more suitable for small scale farmers (Garbutt 2007). When referring to GlobalGAP, we implicitly always include KenyaGAP, except when otherwise stated.

3. It was of advantage that one of the authors of this paper was born and raised in the region and is therefore still integrated into the local networks and speaks the native language of the farmers.

4. The definition of small scale farms varies depending on the author. In the Kenyan context, farms with more than 15 ha can be already regarded as quite large. However, concerning the challenges of implementing GlobalGAP in comparison with $\mathrm{EU}$ farmers, also Kenyan farmers with 15 or even 50 ha face the typical challenges of a small scale farmer regarding implementation and running costs.

5. According to Mithöfer et al. (2008), the total number of farmers producing for export is very volatile but lies at approximately 4,000 in the Mt. Kenya region. Less than 1 per cent of these farms are large farms with more than 1,000 ha and about $80-85$ per cent are small scale farmers with less than 5 ha (FPEAK 2009).

6 . This is possible because the business was either originally a large farm that started exporting itself, or because it was an exporter that started to produce. Both vertical integration developments could be identified.

7. While the routes were identified and crosschecked in various qualitative interviews with experts and stakeholders, the quantitative classification was based on the following selection criteria: Route A: large scale farmer (>1000 ha) and direct exporter. Route B: farmers selling only to an exporter, no use of group certification. Route C: farmers selling to an exporter but not only to an exporter, no use of group certification. Route D: farmers selling to a broker, no use of group certification. Route E left: farmers selling to an exporter, use of group certification. Route E right: farmers selling to a broker, use of group certification. Based on these simple criteria, the table can only give the approximate dimensions of farmers using the distribution channels. Different weaknesses have to be taken into account. First, some of the farmers are using more than one route. Second, farmers can be selling to a single broker without been integrated into a scheme. Third, farmers can be organised in a group without using group certification. Finally 
the usage of certification does in general not mean a formal certification.

8. This procedure is generally and legally acceptable and will not be prosecuted as long as the supermarket chain does not label its products with GlobalGAP, which is usually not the case.

9. In our study, 37 per cent of the farmers had no or primary school education, and the majority had difficulties with written English. This made the GlobalGAP technical manual - which is written in English and exceeds 100 pages - a serious barrier without external help.

10. Here, it will be also interesting to see in how far these practices might change the control system of GlobalGAP in the future and in how far the identified informal arrangements can be sustained. It is important to note that at least some members of the controlling instances of GlobalGAP are already aware of informal arrangements or at least suspect them. Ouma (2010) indicates that GlobalGAP may have plans to establish a GPS-based traceability system, which would threaten the existence of such informal spaces. However, it seems likely that GlobalGAP aims to formally integrate the actual informal scheme arrangements. In the 4.0 version of GlobalGAP which will be obligatory in 2012, vague formulations indicate that in the future GlobalGAP will treat schemes as one farm and therefore the integrated farmers of these schemes can officially switch under the umbrella of the certified exporter farm.

11. The latter is, however, often a fundamental precondition for farmers to consider new techniques or practices.

\section{REFERENCES}

Asfaw, S., D. Mithöfer \& H. Waibel (2008), Foodsafety Standards: A Catalyst for the Winners - a Barrier for the Losers? The Case of GlobalGAP in Horticultural Export from Kenya. Fresh perspectives. London: IIED.

Aster (2009), Advanced Spaceborn Thermal Emission and Reflection Radiometer. Available at <http://www.gdem.aster.ersdac.or.jp/index.jsp>. Accessed on 12 September, 2009.

Barrett, H., B. Ilbery, A. Browne \& T. Binns (1999), Globalization and the Changing Networks of Food Supply: The Importation of Fresh Horti-
culturalProduce from Kenya into the UK. Transactions of the Institute of British Geographers, 24, pp. 159-174.

Biernacki, P. \& D. WAldorf (1981), Snowball Sampling. Problems and Techniques of Chain Referral Sampling. Sociological Methods and Research, 10, pp. 141-163.

Brown, O. (2005), Supermarket Buying Power, Global Commoditiy Chains and Smallholder Farmers in the Developing World. In: H.D.R. OfFice, ed., Human Development Report 2005. New York: UNDP.

Castells, M. \& A. Portes (1989), World Underneath: The Origins, Dynamics and Effects of the Informal Economy. In: A. Portes, M. Castells \& A. Bentoon, eds., The Informal Economy: Studies in Advanced and Less Developed Countries, pp. 11-37. Baltimore, MD: Johns Hopkins University Press.

Chen, M. (2004), Rethinking the Informal Economy: Linkages with the Formal Economy and the Formal Regulatory Environment. EGDI and UNUWIDER Conference Unlocking Human Potential: Linking the Informal and Formal Sectors. 17-18 September 2004, Helsinki.

Coe, N., P. Dicken \& M. Hess. (2008), Global Production Networks: Realizing the Potential. Journal of Economic Geography, 8, pp. 1-25.

Dolan, C. \& J. Humphrey. (2000), Governance and Trade in Fresh Vegetables: The Impact of UK Supermarkets on the African Horticulture Industry. Journal of Development Studies, 37, pp. 147176.

Dolan, C. \& J. Humphrey. (2004), Changing Governance Patterns in the Trade in Fresh Vegetables between Africa and the United Kingdom. Environment and Planning A, 36, pp. 491-509.

EPC (2011), Supply Survey on Horticultural Products. Nairobi: Export Promotion Council.

FPEAK (2009), Mündliche Auskunft durch die FPEAK Hauptgeschäftsstelle. Nairobi: FPEAK.

FPEAK (2011), Fresh Produce Exporters Association of Kenya. Nairobi: FPEAK.

Garbutt, N. (2007), Food Quality Schemes in the International Context: KenyaGAP Experiences and Lessons Learnt. Food Quality Certification. Brussels: EurepGap.

Gereffi, G., J. Humphrey \& T. Sturgeon (2005), The Governance of Global Value Chains. Review of International Political Economy, 12, pp. 78-104.

Gibbon, P., J. Bair \& S. Ponte (2008), Governing Global Value Chains: An Introduction. Economy and Society, 37, pp. 315-338. 
GlobalGAP (2011), GlobalGAP. Available at <http://www.globalgap.org/> Accessed on 21 February 2010.

GraffHam, A. \& J. Cooper (2008), Making GlobalGAP smallholder friendly. Fresh Insights. London: Natural Resources Institute University of Greenwich.

Graffham, A., E. Karehu \& J. MacGregor (2007), Impact of EurepGAP on Small-scale Vegetable Growers in Kenya. Fresh Insights. London: International Institute for Environment and Development.

HCDA (2010), Horticultural Crops Development Authority. Available at <www.hcda.or.ke/> Accessed on 12 March 2010.

Humphrey, J. (2008), Private Standards, Small Farmers and Donor Policy: EUREPGAP in Kenya. IDS Working Paper. Brighton: Institute of Development Studies. ILRI (2007), GIS services. Nairobi: ILRI.

JAFFeE, S. (2005), Food Safety and Agricultural Health Standards: Challenge and Opportunities for Developing Country Exports. Report 31207. Washington, DC: World Bank.

KHDP (2007), EurepGAP an opportunity, not threat for Kenyan small farmers. Available at <http:// www.kenyaag.org/sstories.asp $>$. Accessed on 12 March 2010.

Kulke, E. (2009), Informal Dynamics of a Megacity the Case of Dhaka, Bangladesh. Die Erde, 140, pp. 1-2.

Maertens, M. \& J. Swinnen (2006), Trade, Standards, and Poverty: Evidence from Senegal. LICOS Discussion Papers. pp. 1-38. Leuven: Katholieke Universiteit Leuven.

McCulloch, N. \& M. Oта (2002), Export Horticulture and Poverty in Kenya. IDS Working Paper. Brighton: IDS.
Minot, N. \& M. Ngigi (2003), Are Horticultural Exports a Replicable Success Story? Evidence from Kenya and Côte d'Ivoire. InWEnt, IFPRI, NEPAD, CTA conference 'Successes in African Agriculture'. 1-3 December, Pretoria.

Mithöfer, D., E. Nang'ole \& S. Asfaw (2008), Smallholder Access to the Export Market: The Case of Vegetables in Kenya. Outlook on Agriculture 37, pp. 203-211.

Mwangi, T. (2008), Impact of Private Agrifood Standards on Smallholder Incomes in Kenya. Nairobi: Kenya Horticultural Development Programme.

NADvi, K. (2008), Global Standards, Global Governance and the Organisation of Global Value Chains. Journal of Economic Geography, 8, pp. 323-343.

Ouma, S. (2010), Global Standards, Local Realities: Private Agrifood Governance and the Restructuring of the Kenyan Horticulture Industry. Economic Geography, 86, pp. 197-222.

SingH, B. (2002), Nontraditional Crop Production in Africa for Export. In: J. JANick \& A. Whipkey, eds., Trends in New Crops and New Uses, pp. 86-92. Alexandria, VA: ASHS Press.

TradeDimensions (2010), TOP-firmen 2010 - Standardwerk über den Deutschen Lebensmittelhandel. Frankfurt Am Main: The Nielsen Company (Germany) GmbH.

Waitathu, N. (2008), Kenyan Horticulture: Weathering the Political Storm? New Agriculturist. Available at <http://www.new-agri.co.uk/08/02/ develop/dev1.php>. Accessed on 26 March 2008. 